\title{
Analysis the Role of Headmaster in Applying Quality of Education in Primary School Districts, Aceh Barat
}

\author{
Musdiani $^{1}$, Mardhatillah ${ }^{2}$, Khausar ${ }^{2}$ \\ ${ }^{1}$ STKIP Bina Bangsa Getsempena, Aceh, Indonesia \\ ${ }^{2}$ STKIP Bina Bangsa Meulaboh Aceh, Indonesia \\ mardhatillah.atjeh@gmail.com
}

\begin{abstract}
The aim of this Research is to find out the headmaster's role in implementing quality education management in primary school (SDN) Gunung Keling, Meureubo district, Aceh Barat Regency, to find out what constraints the principal faces in implementing quality management of education in primary school (SDN) Gunung Keling, Meureubo district, Aceh Barat regency. The study used a qualitative approach. This type of Research is descriptive (descriptive research). Research time is on August 8 to 27, 2018. His data collection techniques such as: observation methods, interview methods and documentation methods. The research data to be analyzed in this study is the role of the headmaster in implementing education quality management in primary school of Gunung Keling, Meureubo district, Aceh Barat regency, namely: the role of the headmaster as Educator, Manager, Administrator, Supervisor, Leader and Motivator. What obstacles faced by headmaster in implementing education quality management in primary school of Gunung Keling, Meureubo district, Aceh Barat regency, seen from the results of the study are: to overcome the obstacles to improving teacher quality carried out is to continuously carry out communication and educational quality culture campaigns for teachers who are still low on awareness and in overcoming the lack of teaching staff for permanent subjects, the school requests teachers to work through the Aceh Barat district Education Office.
\end{abstract}

Keywords : analysis; role of headmaster; quality management of education.

\section{Introduction}

Education is key to the progress of a nation. As Iwantoro has put forward (2014:53) education is a very important issue in the development of this nation and the country. The purpose of Education is to direct the growing potential of learners to be a man of pious care to the One God Almighty, qualified, possessed of sublime pekerti ability and virtuousness. Education has a very strategic role in determining the direction of the forthcoming of the nation's quality of community knowledge.

The improvement in educational quality strongly emphasizes the importance of the role of the school as an autonomous primary offender and the role of the principal in developing education. The school needs to be given trust to organize and take care of itself according to environmental conditions. Schools as autonomous institutions are given opportunities to administer in the coordination process to achieve educational goals (Soebagio, 2013:5-6).

The first education passed and accepted a child was education in the family. Any child of cendrung who is heard, seen, experienced and taught by his parents both knowledge, skill, forming a manner of conduct everything received is likely that everything in the family will continue to be practiced outside the home or the social environment (Mardhatillah, 2018)

School learning activities are a major activity in the improvement of the quality of national education. Through the teaching learning process is expected to be achieved educational goals in the form of learner behavior changes. This learning process requires language to allow humans to interconnect and communicate, share experiences with each other, learn from others, and improve self-intellectuality (Anzar \& Mardhatillah, 2018) 
According to Sardiman (2015:125) the quality of the learning process is closely related to the teacher's role and duties in the school, as teachers are directly confronted with students in the conduct of education. Teachers are one of the humane components of the teaching learning process, which comes into play in the potential human resource-building effort (Mardhatillah, et al 2019) Therefore, teachers should play an active role and can place their standing as professional power, in accordance with the growing demands of society. In this case teachers are not solely as teaching teachers who only do science transfer, but also as educators who perform both value transfers as well as as guidance counselors who provide briefing and lead students in learning. Learning is a modification or reinforcing behavior through experience. According to him, this experience can be obtained from interactions between individuals with his environment (Wirdaningsih \& Mardhatillah, 2016)

Teachers are educators who play a role as a determinant of the success of educational goals, because teachers directly interact with students. The teacher is the backbone of educational activities, especially those related to the learning process activities. Therefore in the management of learning the role of the teacher is very important, so the teacher must always improve its quality (Sardiman, 2015: 126).

The headmaster acts as a function of encouragement, influence, in an educational organization, and as an example for educators (Musdiani, 2018). With this role the principal can run an organization and mobilize educators, because educators need an organizational driver in this case as the driver is the leader of the organization or the institution itself, because in an organization between leaders and subordinates must work together on achieving goals . Such goals require professional leaders and those who are leaders are principals (Musdiani, 2013)

The headmaster as the highest leader in the school is considered successful if he can improve teacher performance through various forms of coaching activities on the ability of teachers to carry out learning in schools (Soebagio, 2013: 160). For this reason, the principal must be able to carry out his roles and responsibilities as an education manager, education leader, education supervisor and administrator. The principal is expected to be able to create a comfortable and conducive working atmosphere in the school, so that every teacher can work optimally.

Based on the results of observations on March 10, the authors obtained that the phenomenon that occurred in primary school Gunung Keling teachers was a tendency to weaken teacher performance which can be seen from the teacher's performance at theprimary school Gunung Keling level: $75 \%$ of teachers had not implemented learning strategies varies, $75 \%$ of teachers have not implemented an effective learning activity structure, $80 \%$ of teachers have not improved teaching performance and 50\% of teachers in developing syllabus have not conducted context analysis.

The author also observes the presence of leadership of principals who have not demonstrated their function as leaders. Besides that the condition of the school work climate which according to the author is also not conducive. This is based on the results of interviews with some of the teachers of primary school Gunung Keling. Information is obtained: there are still many complaints from teachers relating to the management process carried out by school principals, the work atmosphere in some schools is not conducive so that it influences teachers' morale. open management and involving all teachers in policy making and decision making, there are still a few principals who are willing to give rewards to teachers who excel, some schools have not evenly distributed the tasks and authorities to teachers, so that they often cause things that can hamper the implementation of the learning process in school. 


\section{Review of Literature}

According to Soejono (2012: 237) "The role is a prihal concept of what individuals can do that is important for the social structure of society, roles include norms and values that are developed in accordance with a person's position or place in society, a role in this sense is a series of rules that guide a person in social life.

The author concludes that the role is the task or function of someone who has been entrusted by a particular party and has a strategic position to contribute both in the form of thought, energy or material, so that it can carry out its role in accordance with what is expected from the job.

School as an organization has almost the same organizational structure as other organizations. If there is a leader in the organization called the chairman, then in the school the leader is called the principal. The headmaster consists of two words namely "head" and "master". The word "head" has the understanding of being a chairman or leader in an organization both in the education and non-education fields. While the notion of "master" is a formal institution that is used as the place for the learning process to take place.

According to Wahjosumidjo (2017: 83), the headmaster can be defined as "a functional teacher who is given the task of leading a school where a teaching and learning process is held, or a place where there is interaction between the teacher who gives lessons and students who receive the lesson". In line with the definition above, the headmaster is someone who has the duty to lead and be responsible in a school education institution.

Every human being has different characteristics. Likewise, the headmaster has several characteristics. According to Mulyasa (2013: 23), the characteristics of headmaster who have a complete vision can be identified including:

1) Intend to worship in carrying out their duties.

2) Religion and obeying their duties.

3) Intend to be both the headmaster

4) Valid in solving problems.

5) Believing that working in a school environment is worship and soul calling.

6) Be tawadhu (humble).

7) Desire to advance school.

8) Not too ambitious about material rewards and the results of their work.

9) Responsible for all his words and actions.

From some of the characteristics above it can be concluded that the characteristics possessed by the headmaster must be perfect both the perfection of the heart and soul.

The headmaster's job as a leader is not easy and takes considerable responsibility for the progress of the school. Therefore, to become a headmaster must fulfill several conditions. According to Daryanto (2015: 92), the following conditions that must be owned by the headmaster include:

a. Have a diploma in accordance with the provisions / regulations set by the government.

b. Have enough work experience, especially in schools that are similar to the school they lead.

c. Having good personality traits, especially attitudes and personality traits needed for educational purposes. 
d. Having extensive expertise and knowledge, especially getting to know the fields of work knowledge needed for the school he leads.

e. Have ideas and initiatives that are good for the progress and development of the school.

Therefore, these conditions must be met by a headmaster as the duty bearer in leading the school.

Not only teachers are said to be educators, headmaster can be said to be educators. The task of an educator is to carry out activities in planning, managing and evaluating learning. According to Sagala (2013: 136) educators carry out planning activities such as compiling learning tools, management activities implementing effective and efficient learning strategies, and evaluation activities improving learning systems, facilitating and encouraging teachers to continuously improve their competencies. As an educator, the principal also functions to guide students, teachers and other education personnel.

The headmaster has several roles in carrying out his duties. One of the roles of headmaster is as a manager. According to Wahjosumidjo (2017: 94), management is the process of planning, organizing, leading, and controlling the business of the members of the organization and the utilization of all organizational resources in order to achieve the stated goals. A manager or principal is essentially a planner, organizer, leader, and controller. According to Asmani (2014: 184), the following is the role of the principal as a manager, namely:

a. Hold predictions on the future of the school.

b. Innovate by taking initiatives and creative activities for school progress.

c. Creating strategies or policies to succeed innovative minds.

d. Arrange planning, both strategic planning and operational planning.

e. Find educational resources and provide educational facilities.

f. Control or control the implementation of education and the results.

The existence of managers in an organization is very necessary because the organization as a tool used to achieve organizational goals. Similarly, the role of the headmaster as a manager aims to achieve school goals.

The headmaster has several roles in carrying out his duties as a school leader. One of the roles of the headmaster is as an administrator. According to Danim (2016: 32), administration can be defined as a process of cooperation between two or more people to achieve certain goals productively. Productive contains effective and efficient meanings. Efficiency refers to work processes, while effectiveness refers to results. While administrators are people who carry out administration by carrying out activities relating to the implementation of wisdom to achieve a goal.

According to Asmani (2014: 187), the principal as an administrator has several tasks, namely:

\section{a. Planning}

The headmaster must think about and formulate a program of goals and actions to be taken. According to Sagala (2013: 61), planning is a continuous process, please note that there are no plans that are final. School planning is structured in an effort to streamline school programs, improve the quality of learning services, and initiate change programs through collective efforts with teachers and education staff with predetermined goals.

\section{b. Organizing}


The headmaster must be able to organize school resources. According to Sagala (2013: 64), organizing is the level of ability of regional heads, heads of education offices, headmaster to determine targets, the division of tasks and responsibilities, determine task implementing personnel, determine the tools needed, allocate time, funds, and resources school power.

c. Briefing

The headmaster must be able to direct and influence all human resources to carry out his essential tasks. According Sagala (2013: 64), directing (directing) is a direction given to members of the organization, so that they become knowledgeable employees and will work effectively towards the goals set by the organization.

\section{d. Coordination}

The headmaster conducts coordination with school residents in carrying out their duties as administrators. According to Sagala (2013: 68), coordination (coordinating) is a regular synchronization of individual efforts related to their number, time, and purpose, so that actions can be taken simultaneously towards the goals set.

The headmaster has several roles in carrying out his duties. One of the roles of the headmaster is as a supervisor. According to Asmani (2014: 188), supervision is an activity of fostering and by helping growth so that everyone experiences an increase in personal and professional. According to Daryanto (2015: 171), the purpose of supervision is to find out whether all regulations, orders or prohibitions are made in accordance with the instructions. The principal as a supervisor provides services to the teacher to improve teaching by providing guidance to improve and develop the abilities of teachers and schools.

\section{Research Method}

In this study it used a qualitative approach. In qualitative approaches of truth is relative, its implementation adapts to the situation and conditions at hand, its goal of gaining an understanding of reality through inductive thought processes, the results of qualitative research presented in narrative descriptive form (Ibn, 2015:32).

The type of research is field research or field research, because what is examined is in accordance with what is in the field directly.

This research will be conducted at primary school Gunung Keling, Meureubo District, Aceh Barat Regency. The time of implementation in this study was carried out in August 2018 and according to the academic calendar in the implementation of the odd semester teaching and learning process.

Data collection techniques in this study are observation methods, documentation methods, and interview methods.

The technique of analysis data, researchers use descriptive methods that are methods that researchers method attempting to describe and interpret objects according to what they are. In this regard, researchers are trying to describe and expose the results of observations, interviews as well as documentation about the principal's role in implementing the quality management of education primary school of Gunung Keling.

\section{Discussion}


At the time in the field when research was conducted with interview techniques, researchers got results regarding the role of the headmaster of primary school Gunung Keling namely as follows:

\section{Headmaster as an educator}

Interview with a teacher: "Throughout my observations, the headmaster created a conducive school climate" (Interview with primary school teacher of Gunung Keling, on August 6, 2018).

The results of the interview with the headmaster are as follows: "As the headmaster, always remind the teachers so as much as possible to direct students / students to develop their potential" (Interview with the headmaster of primary school Gunung Keling, on 7 August 2018).

\section{Headmaster as manager}

Interview with a teacher: "The ability of the headmaster in preparing the school program in my opinion is very good" (Interview with primary school teacher og Gunung Keling, on August 6, 2018).

Whereas according to the principal as follows: "So far there have been three things that I have done as headmaster according to his role as manager, namely:

a. Empower education staff.

b. Provide opportunities for education staff to improve their profession.

c. Encourage the involvement of all education staff in each activity in the school (participatory) "( Interview with head master of primary school Gunung Keling, on 7 August 2018).

\section{Headmaster as Administrator}

Interview with the teacher: "As a person I am always assisted by the headmaster in finance" Interview with primary school teacher of Gunung Keling, on August 6, 2018).

The results of the interview with the headmaster of the following: "So far in managing financial administration, I am the headmaster of the school assisted by the treasurer to realize in the development of routine financial administration" (Interview with th headmaster of primary school Gunung Keling, on August 6, 2018).

\section{Headmaster as a supervisor}

Interview with several teachers: "Usually at the end of each month the headmaster supervises all teachers" (Interview with primary school teacher of Gunung Keling, on August $6,2018)$.

The other thing stated by the head was as follows: "Some of the supervision programs that I always carried out were supervision of extracurricular activities, supervision of examinations, library activities and impromptu supervision" (Interview with the headmaster of primary school of Gunung Keling, on August 6, 2018).

\section{Headmaster as leaders}

The results of the interview with the teacher: "During my time as a teacher, I saw that in coordinating headmaster, I was able to establish harmonious relations with the community" (Interview with primary school teacher of Gunung Keling, on August 6, 2018). 
The next interview with the headmaster was as follows: "I am the headmaster as a leader in the school striving to continually build and develop various innovations to advance this school" (Interview with th headmaster of primary school Gunung Keling, on August 6, 2018).

\section{Principals as Innovators}

The results of the interview with the teacher: "As a teacher in this school, in my opinion, the headmaster as an innovator always strives to carry out various updates in the school especially those related to student activities" (Interview with primary school teacher of Gunung Keling, on August 6, 2018).

Next interview with the school headmaster: "One of my forms of innovation as a headmaster in this regard is the school haedmaster's efforts to improve the professionalism of education staff in schools" (Interview with the headmaster of primary school Gunung Keling, on August 6, 2018).

\section{Headmaster as a motivator}

The results of the interview with the teacher: "In learning activities, the headmaster gives a target to the teacher so that they must first plan for what he motivates students" (Interview with primary school teacher of Gunung Keling, on August 6, 2018).

The results of the research on the obstacles faced by headmaster to improve the quality of education is that there are still teachers who are low in awareness of improving teacher quality, there are still teachers who are less competent and still lack the number of teachers as needed. While the solution taken by the headmaster of primary school Gunung Keling in overcoming the obstacles to improving the quality of education is by continuously communicating and campaigning on quality education culture for teachers who are still low on awareness and applying for teacher staff through the Aceh Barat District Education Office, as well as conducting appointments honorarium teachers to overcome the shortage of teachers.

The condition of teachers who are still low in awareness of improving teacher quality, and far from professional qualifications will have an impact on the learning process that should be held interactively, inspirationally, and pleasantly still far from expectations. Even so, the educational atmosphere that challenges and motivates creative students cannot be applied. In addition, the condition of the lack of teachers as needed is a serious problem, because it can potentially lead to a decrease in the quality of education in this school. The shortage of teachers is a common phenomenon that occurs, due to the fact that there are teachers who retire, there is an increase in the number of students / classes, or there may be errors related to the preparation of job analysis, and not the teacher placement and transfer process.

\section{Conclusion}

The role of the headmaster in implementing education quality management in primary school of Gunung Keling in Meureubo District, Aceh Barat Regency, seen from the results of research that: Headmasters in carrying out their leadership must have roles in implementing education quality management, as follows: the headmaster as Educator ( have a strategy to improve the professionalism of educators), Managers (implement, lead, plan for predetermined goals), Administrators (compile school financial records), Supervisors (supervise the work carried out by educators). 
Budapest International Research and Critics in Linguistics and Education (BirLE) Journal

Volume 2, No 3, August 2019, Page: 27-35

e-ISSN: 2655-1470 (Online), p-ISSN: 2655-2647 (Print)

www.bircu-journal.com/index.php/birle

emails: birle.journal@gmail.com

birle.journal.qa@gmail.com

Whatever constraints the headmaster faces in implementing education quality management in Gunung Keling, Mereubo District, Aceh Barat Regency is seen from research results that are: the constraints the headmaster faces to improve quality education is that there are still teachers who are low awareness of teacher quality improvement, still less competent teachers as well as still lack of Primary School (SMPN) Gunung Keling in overcoming obstacles to quality improvement.

\section{Refeerences}

Abdurrahmat, 2016, Metodologi Penelitian dan Teknik Penyusunan Skripsi, Jakarta: Rineka Cipta

Andi, 2014, Metode Penelitian Kualitatif dalam Perspektif Rancangan Penelitian, Yogyakarta: Ar-Ruzz Media

Anzar, S. F., \& Mardhatillah, M. (2018). Analisis Kesulitan Belajar Siswa Pada Pembelajaran Bahasa Indonesia di Kelas V SD Negeri 20 Meulaboh Kabupaten Aceh Barat Tahun Ajaran 2015/2016. Bina Gogik, 4(1).

Arikunto, 2013, Prosedur Penelitian, Jakarta: Rineka Cipta

Asmani, 2014, Manajemen Sekolah, Jogjakarta: Diva Press

Cyril, 2014, Gerakan Menciptakan Sekolah Unggulan, Jakarta: Lembaga Indonesia Adidaya

Danim, 2016, Kinerja Staf dan Organisasi Perspektif Pendidikan, Pelatihan,. Pengembangan dan kewidyaiswaraan Berbasis Kinerja, Bandung: Pustaka Setia

Daryanto, 2015, Evaluasi Pendidikan, Jakarta: Rineka Cipta

Gaspersz Vincent, 2010, Total Quality Management, Jakarta: Gramedia Pustaka Utama

Hadiyanto, 2014, Mencari Sosok Desentralisasi Manajemen Pendidikan di Indonesia, Jakarta: Rineka Cipta

Hari, 2015, Manajemen Peningkatan Mutu Berbasis Sekolah; Peningkatan Mutu Pendidikan Melalui Implementasi KBK, Bandung: Cipta Lekas Garafika

Husaini, 2016, Manajemen Teori, Praktek Dan Riset Pendidikan, Jakarta: Bumi Aksara

Ibnu, 2015, Dasar-dasar Metodologi Kualitatif Dalam Pendidikan, Semarang: Rajawali Press

Idochi,2013, Administrasi Pendidikan dan Manajemen Biaya Pendidikan, Jakarta:

Rajagrafindo Persada

Iwantoro, 2014, Kompetensi Supervisi Kepala Sekolah Meningkatkan Kinerja Guru dalam Rangka Mencapai Tujuan Pendidikan, Jurnal Ilmu Tarbiyah “At-Tajdid”. Vol. 3 No. 2

John, 2016, Kamus Inggris Indonesia, Jakarta: Gramedia

Lukman, 2015, Kamus Besar bahasa Indonesia, Jakarta: Balai Pustaka

Nasution, 2014, Manajemen Mutu terpadu, Jakarta: Ghalia Indonesia

Mahmud, 2014, Kamus Arab Indonesia, Bandung: Al-Ma'arif

Mardhatillah, M., \& Trisdania, E. (2018). Pengembangan Media Pembelajaran Berbasis Macromedia Flash Untuk Meningkatkan Kemampuan Membaca Siswa Di Sd Kelas Ii Negeri Paya Peunaga Kecamatan Meureubo. Bina Gogik, 5(1).

Mardhatillah, M., Verawati, V., Evianti, E., \& Pramuniati, I. (2019). BAHAN AJAR INTERAKTIF BERBASIS KEARIFAN LOKAL MELALUI PENDEKATAN SAINTIFIK PADA PEMBELAJARAN BAHASA INGGRIS. Genta Mulia: Jurnal Ilmiah Pendidikan, 10(1).

Mardhatillah, M. (2018). PENGEMBANGAN MEDIA PEMBELAJARAN INTERAKTIF BERBASIS TIK (TEKNOLOGI INFORMASI DAN KOMUNIKASI) PADA MATERI 
TEKS NARASI DI KELAS IV SD/MI. Bina Gogik: Jurnal Ilmiah Pendidikan Guru Sekolah Dasar, 2(2).

Margono, 2013, Metodologi Penelitian Pendidikan, Jakarta: Rineka Cipta

Mujamil, 2014, Pesantren Dari Transformasi Metodologi Menuju Demokratisasi Institusi, Jakarta: Erlangga

Mulyasa, 2007, Standar Kompetensi dan Sertifikasi Guru, Bandung: Remaja. Rosdakarya 2013, Manajemen Berbasis Sekolah, Konsep, strategi dan. Implementasi, Bandung:

Remaja Rosdakarya

Musdiani, M. (2018). The Influence of Problem-Based Learning Model on Learning IPS. Jurnal Ilmiah Peuradeun, 6(2), 267-276.

Musdiani, M. (2013). Minimizing Traditional Approach in Indonesian Education. Visipena Journal, 4(1).

Sari, S. M., \& Mardhatillah, M. (2018). PERBEDAAN PENGARUH METODE INKUIRI DENGAN METODE KONVENSIONAL TERHADAP HASIL BELAJAR BAHASA INDONESIA. Bina Gogik: Jurnal Ilmiah Pendidikan Guru Sekolah Dasar, 5(2).

Khausar, K. (2018). Pengaruh Penerapan Metode Pembelajaran Guru Yang Bervariasi Terhadap Peningkatan Hasil Belajar Pada Siswa Kelas Xi Sma Negeri 1 Labuhanhaji Timur Aceh Selatan. Genta mulia: jurnal ilmiah pendidikan, 5(2).

Khausar, K., Putrawan, I. M., \& Neolaka, A. (2019, January). The Effects of Teacher's Leadership, Personality and Cultural Values toward Motivation of Healthy Life. In International Conference on Islamic Education (ICoIE 2018). Atlantis Press.

Wirdaningsih, W., \& Mardhatillah, M. (2016). Penerapan Media Audio-Visual Terhadap Keaktifan Pada Materi Hubungan Antara Sumber Daya Alam Dengan Lingkungan Siswa Kelas IV SD Negeri Pasi Teungoh Kecamatan Kaway XVI. Bina Gogik, 3(2). 